\title{
A revision of five braconid species described by SzÉPLIGETI in 1913 and deposited in Senckenberg Deutsches Entomologisches Institut (Hymenoptera: Braconidae)
}

\author{
With 79 figures
}

JENÖ PAPP ${ }^{1}$

${ }^{1}$ Department of Zoology, Hungarian Natural History Museum, H-1431 Budapest, pf. 137, Hungary. - j.papp1933@gmail.com Published on 2013-12-20

\section{Summary}

Five braconid species described by Gy. SzÉPligeti in 1913 (Epimicrodus pumilus, Campyloneurus similis, Curriea nigriventris, Mesosoma elegans, Plaxopsis pulchricaudis) are redescribed and compared with the species which they most resemble. The type specimens of these species are deposited in the Senckenberg Deutsches Entomologisches Institut (Müncheberg).

\section{Zusammenfassung}

Die von Gy. SzÉPLIgeti in 1913 beschriebenen fünf Braconidae-Arten (Epimicrodus pumilus, Campyloneurus similis, Curriea nigriventris, Mesosoma elegans, Plaxopsis pulchricaudis) werden revidiert und mit nahestehenden Arten verglichen. Die Typusexemplare befinden sich im Senckenberg Deutsches Entomologisches Institut (Müncheberg).

\section{Keywords}

Agathidinae, Braconinae, type designation, synonymy, redescription, affinity, identification key.

\section{Introduction}

In 1913 Gy. Szépligeti described six new braconid species from tropical Africa, they are as follows (with the currently valid names in brackets): Epimicrodus pumilus (= Bassus szepligetii nom. n.), Campyloneurus similis, Curriea nigriventris, Mesobracon elegans, Plaxopsis pulchricaudis and Iphiaulax conradti (= Serraulax conradti). Besides the new species eleven known species were reported together with new faunistic data (SzÉPligeti 1913).
In connection with my revisionary project of SzÉPLIGETI's braconid types A. TAEgER (Müncheberg) kindly allowed me to examine the types of the six braconid species by SzÉPLIGETI listed above and deposited in the Senckenberg Deutsches Entomologisches Institut, Müncheberg. The examination confirmed that the original names of four species remain valid, whilst two species received new combinations of names. In this paper five species are redescribed, the redescription of the sixth species (Serraulax conradti) is presented in a previous paper (PAPP 2011). 


\section{Taxonomic part}

In the redescription the following abbreviations are used (after van ACHTERBERg 1993: 4-5):

Eye $-\mathrm{OOL}=$ ocellar-ocular line, i.e. shortest distance between hind ocellus and compound eye, $\mathrm{POL}=$ postocellar line, i.e. shortest distance between hind two ocelli.

Forewing veins $-c u-a=$ nervulus, $m-c u=$ transverse medio-cubital vein, $r=$ first section of the radial vein, $r-m=$ transverse radio-median vein, $2 b-S R=$ the petiole vein of the second submarginal or areole cell (of agathines), $1-M=$ basal vein, $2-M=$ third section of the cubital vein, $1-R 1=$ first section of the metacarpal vein, $2-R 1$ $=$ second section of the metacarpal vein, $1-S R-M=$ first section of the cubital vein, $2-S R=$ first transverse cubital vein, $3-C U 1=$ basal section of subdiscoidal vein, $3-S R=$ second section of the radial vein, $S R 1=$ third section of the radial vein.

Hind wing veins $-c u-a=$ nervellus, $1-2 S R=$ first and second sections of the radial vein.

Surface sculpture terminology is applied after EADY (1968) and HARRIS (1979).

\section{Agathidinae}

\section{Bassus szepligetii nom. n.}

(Figs 1-10)

Epimicrodus pumilus SzÉPLIGeti, 1913: 385, female(s), type locality: "Pretoria" (Republic of South Africa), female lectotype (hereby designation, examined in 2005) in Senckenberg Deutsches Entomologisches Institut, Müncheberg.

Crassomicrodus pumilus (SzÉPligeti): Shenefelt 1970: 382 (after BRUES 1924: 144, literature up to 1926).

\section{Taxonomic notes:}

The genus Epimicrodus was described by AsHMEAD in 1900; later the genus was synonymized with Crassomicrodus Ashmead, 1900 by Bradley (1916) and Muesebeck (1927). The Crassomicrodus species are restricted to the Nearctic / Neotropic Regions, i.e. in tropical Africa are not distributed (SHARKey 1997). Having examined the female lectotype of Epimicrodus pumilus it proved to represent the genus Bassus Fabricius, 1804 (= Microdus Nees, 1812) comb. $\mathrm{n}$. The species name pumilus is preoccupied within Bassus by B. pumilus (RaTZEBURG, 1844) and therefore hereby replaced.

\section{Labels of the lectotype:}

(first label) "Pretoria" (printed) / "2.4.12." (handscript) / "A.J.T. Janse" (printed); (second label, my handscript)
"Republic of South Africa"; third label is with SzÉPLIGETI's original name label; fourth label is the lectotype card; fifth label is with the actual name Bassus szepligetii nom. n. present identification. (Labels 2, 4 and 5 were attached by me). - Lectotype is in fairly good condition: (1) micropinned by mesosoma (pin through prescutellar sulcus / mesosternum); (2) right flagellum missing, left flagellum missing distal of flagellomeres 5; (3) missing: right middle tarsus and left hind tarsus.

\section{Redescription of the lectotype:}

Body $4.5 \mathrm{~mm}$ long. Scape twice as long as apically broad and in lateral view somewhat expanded: first flagellomere 2.5 times and fifth flagellomere 2.2 times longer than broad (Fig. 1). - Head in dorsal view transverse (Fig. 2), 2.4 times as broad as long, eye three times longer than temple, temple strongly receded. Ocelli middle-sized, OOL somewhat longer than POL. Eye in lateral view 1.4 times as high as wide and almost four times wider than gena (Fig. 3). Face somewhat wider between eyes than high between antennal socket and clypeal margin. Malar space somewhat less than 0.5 times as long as height of eye. Width of clypeus equal to malar space (Fig. 4). Head polished, face and clypeus with very fine hair-punctures, shiny.

Mesosoma in lateral view 1-3 times as long as high, polished with very fine hair-punctures. Notaulix line-form, evenly deep and subcrenulated. Precoxal suture crenulated. Propodeum evenly rugulose. Hind femur 2.7 times as long as broad medially (Fig. 5). Inner spur of hind tibia just shorter than half length of basitarsus (Fig. 6). Claw clearly curved and with a distinct basal lobe (Fig. 7).

Forewing as long as body. Peterostigma (Fig. 8) 2.8 times as long as wide and issuing $r$ from its middle. SR1 bent, second submarginal cell (or areola) petiolate, i.e. second three-sided submarginal cell joining to $r$ by vein $2 b-S R$.

First tergite (Fig. 9) evenly broadening posteriorly, somewhat broader behind than long, pair of spiracles before middle of tergite, finely striated. Second tergite transverse, almost 2.5 times as broad behind as long medially, together with further tergites polished. Hypopygium small and pointed (Fig. 10), ovipositor sheath somewhat longer than length of hind tibia + tarsus combined.

Body ochre yellow. Scape black, pedicel and five flagellomeres blackish. Head black, clypeus and oral organs ochre yellow. Mesosoma black, mesosternum brownish black. Legs ochre yellow, hind tibia yellow apically blackish. Proximal two-thirds of basitarsus yellow, otherwise tarsomeres dark brownish. Wings faintly brownish fumous, pterostigma brown, veins proximo-distally yellowish to brownish.

Male and host unknown. 


\section{Distribution:}

Republic of South Africa.

\section{Taxonomic position:}

Bassus szepligetii is near to Bassus bruesi SHenefelt, 1970 (Agathis bruesi Shenefelt, $1970=$ Bassus (Microdus) aciculatus BRUEs, 1926 nec Bassus aciculatus (AsHMEAD, 1889)) (Tanzania, Uganda), the latter species known to the author only from its original description (BRUES 1926: 285) and redescription (NIXON 1941: 117); the two species are differentiated by rather subtle and less easy recognizable features (the features of $B$. bruesi are cited from the original description of Bassus (Microdus) aciculatus by BRUEs 1926):

1 (2) “Face...as wide between eyes as high from antennae to margin of clypeus. ... Notauli forming discrete crenulated lines anteriorly, broader and smooth behind where they curve inward to meet in a gentle depression just behind the middle; ... Propodeum.... with an elongate median area extending from base to apex. ... Hind femur fully one-third as wide as long. ... First segment [i.e. first tergite] slightly longer than broad at apex.” ㅇ: $5 \mathrm{~mm}$.

Bassus bruesi (SHENEFELT, 1970) comb. $\mathrm{n}$.

2 (1) Face somewhat wider between eyes than high between antennal socket and margin of clypeus. Notauli forming an evenly deep, subcrenulated line not broadening posteriorly. Propodeum without elongate median area, i.e. evenly rugulose. Hind femur one-fourth as wide as long (Fig. 5). First tergite somewhat broader behind than long (Fig. 9). ․: $4.5 \mathrm{~mm}$. Bassus szepligetii nom. n.

Bassus szepligetii is also near to B. conspicuus (WESMAEL, 1837) (Palaearctic Region) because they share a distinctly transverse head in dorsal view (Figs 2, 11), fine striation of first tergite (Figs 9, 12) and yellow ground colour of the body. However, they differ from each other by the features keyed:

1 (2) First tergite somewhat broader behind than long, more broadening posteriorly (Fig. 9). Temple in dorsal view receded (Fig. 2). Forewing: pterostigma wide, 2.8 times as long as wide, second submarginal cell (or areola) petiolate, $1-R 1$ and $2-R 1$ equal in length (Fig. 8). ㅇ: $4.5 \mathrm{~mm}$. Bassus szepligetii nom. $\mathrm{n}$.

2 (1) First tergite somewhat longer than broad behind, less broadening posteriorly (Fig. 12). Temple in dorsal view rounded (Fig. 11). Forewing: pterostigma less wide, four times as long as wide, second submarginal cell (or areola) not petiolate, $2-R 1$ clearly three times longer than 1-R1 (Fig. 13). ㅇ: $4 \mathrm{~mm}$.

Bassus conspicuus (WeSMAEL, 1837)

\section{Braconinae}

\section{Campyloneurus similis SzÉPLIGETI}

(Figs 14-22)

Campyloneurs similis Szépligeti, 1913: 384 female(s), type locality: "Natal, Sarnia" (Republic of South Africa), female lectotype (hereby designated, examined in 2005) in Senckenberg Deutsches Entomologisches Institut, Müncheberg; examined. - Fahringer 1935: 411 (in key) and 425 (redescription). SHENEFELT 1978: 1664 (literature up to 1935).

\section{Labels of the lectotype:}

(first label, printed) "Sarnia (Natal) / 19 Jan. 1912. / A.J.T. Janse"; (second label, printed) "Republic of South Africa"; (third label) "Campyloneurus similis sp. n. (my handscript) / "det. Szépligeti” (printed) "1913” (my handscript); fourth label is SzÉPLIGETI's original one reverse the third label; fifth label is the lectotype card. Lectotype is in good condition: (1) micropinned by mesosoma; (2) both flagelli distally damaged; (3) missing: both ovipositor sheaths, marginal cell of left forewing and fifth tarsomere of right hind tarsus; (4) wings neatly expanded.

\section{Redescription of the lectotype:}

Body $6 \mathrm{~mm}$ long. Scape pyriform, 1.4 times as long dorsally as broad apically (Fig. 14). Both flagella deficient distally, with 26 flagellomeres. First flagellomere almost 1.4 times as long as broad, second to seventh flagellomeres shortening so that further flagellomeres cubic. - Head in dorsal view transverse (Fig. 15), 1.75 times as broad as long, eye 1.6 times as long as temple, temple rounded. Eye in lateral view nearly 1.4 times as high as wide and nearly 1.7 times as broad as temple, temple beyond eye evenly wide (Fig. 16, see arrows). Horizontal diameter of oral opening 1.5 times longer than shortest distance between opening and eye. Head polished, face rugulose-uneven.

Mesosoma in lateral view 1.5 times as long as high, polished. Notaulix distinct, less deep. Propodeum polished, around lunule with short rugulae. Hind femur 3.3 times as long as broad medially (Fig. 17). Claw downcurved, basal lobe as in Fig. 18.

Forewing somewhat shorter than body. Pterostigma (Fig. 19) 2.6 times as long as wide and issuing $r$ just proximally from its middle, $r$ short. Second submarginal cell short, 3-SR 1.7 times as long as 2-SR; SR1 curved, 1.2 times as long as $3-S R$ and raher approaching tip of wing. First discal cell wide, $1-M 1.5$ times as long as $m-c u, 1-S R-M 1.4$ times as long as $1-M$ (Fig. 20). Hindwing: $\mathrm{cu}-a$ straight (Fig. 21, see arrow).

First tergite (Fig. 22) 1.2 times as broad as long, less broadening posteriorly, scutum rugose and its margin finely crenulated. Second tergite transverse, 2.3 times as broad as long medially, antero-median field polished, laterally crenulated, otherwise rugose. Suture between tergites 2-3 straight, deep, crenulated. Tergites 3-5 with 
somewhat weakening rugosity, sixth tergite smooth. Ovipositor sheath long, as long as hind tibia + tarsomeres 1-4 combined.

Antenna blackish. Body light brownish yellow, first tergite and legs yellow. Distal half of hind tibia and hind basitarsus brown to brownish. Wings faintly brownish fumous, pterostigma brown, veins light brown.

Male and host unknown.

\section{Distribution:}

Republic of South Africa.

\section{Taxonomic position:}

Campyloneurus similis is near to C. basalis SzÉPLIGETI, the two species differing from each other as follows:

1 (2) Temple in dorsal view rounded, eye less long, 1.6 times as long as temple (Fig. 15). Forewing: second submarginal cell short, 3-SR 1.7 times as long as 2-SR, SR1 approaching tip of wing (Fig. 19). Second tergite, 2.3 times as broad behind as long medially, weakly rugose; first tergite slightly less broadening posteriorly and with rather transverse rugosity (Fig. 22). Hind femur in lateral view not parallel-sided (Fig. 17). Metasoma beyond first testaceous. $+: 6 \mathrm{~mm}$. - Republic of Souh Africa.

C. similis SzÉPLIGETI, 1913

2 (1) Temple in dorsal view receded, eye long, three times as long as temple (Fig. 23). Forewing: second submarginal cell long, 3-SR 2.1 times as long as 2-SR, SR1 reaching tip of wing (Fig. 24). Second tergite 1.75 times as broad as long medially, strongly rugose; first tergite more broadening posteriorly and with longitudinal striate elements (Fig. 26). Hind femur in lateral view parallel-sided (Fig. 25). Metasoma beyond first tergite black. 우 $7 \mathrm{~mm}$. - Mozambique. C. basalis SzÉPLIGETI, 1906

\section{Curriea nigriventris SzÉPLIGETI}

(Figs 28-35, 39-41)

Curriea nigriventris SzÉPLIGETI, 1913: 383, male(s), type locality: "Kamerun", male lectotype (hereby designated, examined in 2005) in Senckenberg Deutsches Entomologisches Institut, Müncheberg. - FAHrINGer 1928: 156 (in key) and 160 (redescription)

Aphrastobracon nigriventris (SzÉPLIGETI): WATANABe 1950: 301 (comb. n., distribution). SHENEFELT 1978: 1428 (literature up to 1950).

Curriea testaceipes SzÉPligeti, 1914b: 109 female(s), type locality: "Franz. Congo (Chutes de Samlia Riv. N. Gami)", female lectotype (hereby designated, examined in 2010) in Institut royal des Sciences naturelles de Belgique, Bruxelles; examined, syn. n. - FAHRINGer 1928: 155 (in key) and 163 (redescription).

Aphrastobracon testaceipes (SzÉPligeti): WatANABe 1950: 301 (comb. n., distribution). SHENEFELt 1978: 1429 (literature up to 1950).

\section{Taxonomic notes:}

1.) The genera Aphrastobracon Ashmead, 1896 and Curriea AsHMEAD, 1900 are very near to each other and, in fact, the two generic names, Curriea and Megalommum SzÉPLIGETI, 1900 were united (i.e. synonymized) under the valid (or oldest) name Aphrastobracon by WATANABE (1950). QUicke (1987: 84) revalidated these genera and added to them the fourth genus Endovipio Turner, 1922 and within the tribe Aphrastobraconini separated them under the subtribe Aphrastobraconina QUICKE, 2000 (together with further four genera, QUICKE et al. 2000: 111). The taxonomic status of these genera is unclear, however, as expressed by Quicke et al. (l.c.) as follows: "Future phylogenetic studies may lead to some, or all, of the above genera being regarded as derived species groups of others and so generic concepts may subsequently be revised".

2.) The genera Aphrastobracon and Curriea differ in a single and rather subtle feature, namely the apical form of the margin of scape (after QUICKE 1987: 84):

Aphrastobracon: scape in apico-lateral view at most weakly (Fig. 27, see arrow), usually not, emarginate.

Curriea: scape in apico-lateral view deeply emarginate (Fig. 28, see arrow).

\section{Labels of the lectotype of Curriea nigriventris SzÉPLI-} GETI:

(First label, printed) "Kamerun / Conradt" "XI" (handscript); (second label, printed) "Coll. Kraatz"; third label is SzÉPLIGETI's original label, fourth label is the holotype card. - Holotype is in good condition: (1) pinned by mesosoma (through mesoscutum / between pro- and mesosternum); (2) distal part of right antenna missing, i.e. flagellum with 24 flagellomeres; (3) right fore wing missing.

\section{Labels of the lectotype of Curriea testaceipes SzÉPLI-} GETI:

(First label, printed) "Chutes de Samlia / Riv. N. Gamie / Mocgnereys"; (second label, my handscript) "Franz. Kongo / (= Brazzaville / Congo)"; (third label) "Curriea + / testaceipes n. sp." (handscript) "det. Szépligeti” (printed) "1914" (handscript); fourth label reverse and close to the third label, printed red) "Type"; fifth label is the holotype card; sixth label is with the actual name Curriea nigriventris SzÉPL. present identification. (Labels 2, 5 and 6 were attached by me.) - Lectotype is in less good condition: (1) pinned by mesosoma (through lateral part of mesoscutum / prosternum); (2) pair of forewings and right hind wing glued on a separate card; (3) missing: head, right fore and middle legs (except coxae), right hind tibia 
+ tarsus and tarsomeres 4-5 of left hind leg, ovipositor sheath + ovipositor.

\section{Redescription of the male lectotype of Curriea nigri- ventris SzÉPLIGETI:}

Body $7 \mathrm{~mm}$ long. Left antenna somewhat longer than body and with 54 antennomeres. Scape 1.4 times as long as broad apically, distally somewhat broadening, dorsally somewhat longer than ventrally, in lateral view apically deeply emarginate (Fig. 28, see arrow). First flagellomere 2.1 times, further flagellomeres gradually shortening and slightly attenuating so that penultimate flagellomere twice as long as broad. - Head in dorsal view cubic (Fig. 29), 1.5 times as broad as long, eye three times as long as temple, temple receded. Ocelli middle-sized, POL somewhat longer than OOL. Eye in lateral view almost 1.4 times as high as wide, temple 0.3 times less wide than eye (Fig. 30, see arrows). Horizontal diameter of oral opening twice as long as shortest distance between opening and eye. Margin of clypeus carinated. Face with rugae-rugulae elements, medially smooth. Head polished.

Mesosoma in lateral view twice as long as high, polished. Notaulix weakly distinct, smooth. Hind femur five times as long as broad distally (Fig. 31). Hind basitarsus as long as tarsomeres 2-3 combined. Claw curved and widening basally as in Fig. 32.

Forewing as long as body. Pterostigma (Fig. 33) four times as long as wide and issuing $r$ just proximally from its middle, $r$ just longer than width of pterostigma. Second submarginal cell usual in length: $3-S R 1.5$ times as long as $2-S R, S R 1$ bent and reaching tip of wing. First discal cell long, $1-M$ slightly longer than $m-c u$; first subdiscal cell glabrous medially, its form as in Fig. 34 .

First tergite (Fig. 41) 1.65 times as long as broad behind, evenly broadening posteriorly, pair of spiracles before middle of tergite, with a pair of basal keels, scutum striated. Second tergite 1.25 times as broad behind as long, anteriorly with a median and polished area narrowing posteriorly, otherwise tergite striated. Further tergites subrugulose, uneven to almost smooth. Suture between tergites 2-3 almost straight, fairly deep and crenulated.

Body ochre yellow, face yellow. Scape ochre yellow, pedicel and flagellum brownish. Metasoma posteriorly darkening brown. Legs also ochre yellow. Wings subhyaline, pterostigma yellow, veins yellow to light brownish.

\section{Redescription of the female lectotype of Curriea testa- ceipes SzÉPLIGETI:}

Similar to the male lectotype of C. nigriventris. Body $10 \mathrm{~mm}$ long (after SzÉPLIGETI 1914b: 109), without head $7 \mathrm{~mm}$ long. Hind femur 3.6 times as long as broad distally (Fig. 35). Pterostigma four times as long as wide and issuing $r$ just proximally from its middle. Second submarginal cell somewhat longer (than that of male, cf. Fig. 33), 3-SR 1.6 times as long as 2-SR (Fig. 39). First tergite somewhat greater, 1.4 times as long as broad behind, scutum wide (Fig. 40); second tergite transverse, 1.5 times as broad behind as long, its antero-median polished area wide, striation strong (cf. Fig. 41). Ovipositor sheath as long half metasoma (after SzÉPLIGETI 1914a: 109). Body and legs ochre yellow, metasoma posteriorly not darkening brown, wings subhyaline.

Host unknown.

\section{Distribution:}

Cameroon, Republic of Congo (= Congo Brazzaville).

\section{Taxonomic position:}

The species Curriea nigriventris is near to C. antefurcalis SzÉpligeti (Cameroon, Democratic Republic of Congo $=$ Zaire), the features that distinguish between them are restricted to a few body characters as follows:

1 (2) First tergite less broad, female 1.4 times (Fig. 40) and male 1.6 (Fig. 41) times as long as broad behind, second tergite of male 1.25 times as broad behind as long (Fig. 41). Eye in dorsal view three times as long as temple, temple receded (Fig. 29). Forewing: $r$ just longer than width of pterostigma (Figs 33, 39). First discal cell large; first subdiscal cell less wide, $c u-a$ 1.5 times as long as 3-CU1 (Fig. 34). Hind femur 4.6 times $\left({ }^{*}\right)$ and 4.2 times ( 9 ) as long as broad distally (Figs 31, 35). $0^{*}: 6 \mathrm{~mm}$, ㅇ: $9 \mathrm{~mm}$.

C. nigriventris SzÉPLIGETI, 1913

2 (1) First tergite broad, female 1.1 times (Fig. 43) and male 1.2 times (Fig. 42) as long as broad behind, second tergite of male 1.7-1.8 times as broad behind as long (Fig. 43). Eye in dorsal view more than three times as long as temple, temple rounded (Fig. 38). Forewing: $r$ shorter than width of pterostigma (Figs 44-45). First discal cell less large; first subdiscal cell wide, $c u-a$ 1.3 times longer than 3-CU1 (Fig. 46). Hind femur 4.1 times $\left(\sigma^{*}\right)$ and 3.6 times ( 9 ) as long as broad distally (Figs 36-37). $\sigma^{\text {` }}$ \% : 8-10 mm

C. anteurcalis SzÉPLIGETI, 1915

\section{Mesobracon elegans SzÉPLIGETI \\ (Figs 47-56)}

Mesobracon elegans SzÉPLIGeTI, 1913: 385 female(s), type locality: "Kamerun", female lectotype (hereby designated, examined in 2005) in Senckenberg Deutsches Entomologisches Institut, Müncheberg; examined. - BRUES 1926: 239 (in key). FAHringer 1928: 121 (in key) and 127 (redescription). SHENEFELt 1978: 1704 (literature up to 1928).

\section{Labels of the lectotype:}

(First label) "Kamerun / Conradt" (printed) "IX" (handscript); (second label, printed) "Coll. Kraatz"; third label is SzÉPLIGETI's original one; fourth label is the lectotype card. - Lectotype is in good condition: (1) pinned by mesosoma; (2) right flagellum apically 
deficient; (3) fore pair of wings damage at pterostigma (pterostigma itself missing); (4) fifth tarsomere of left hind leg missing.

\section{Redescription of the lectotype:}

Body $15 \mathrm{~mm}$ long. Antenna as long as body (left antenna) and with 78 antennomeres. Scape in outer-lateral view one sixth longer than broad apically and here formed as in Fig. 47. Flagellomeres transverse. - Head in dorsal view transverse (Fig. 48), twice as broad as long, eye protruding and clearly twice as long as temple, temple receded. Eye in lateral view 1.3 times as high as wide and twice wider than temple, temple ventrally broadening (Fig. 49, see arrows). Malar space somewhat shorter than basal width of mandible. Horizontal diameter of oral opening also somewhat longer than shortest distance between opening and eye. Face uneven with disperse subpunctures, frons finely granulate with a few subrugulae; otherwise head polished.

Mesosoma in lateral view 1.6 times as long as high. Medio-transverse sulcus of pronotum smooth. Notaulix anteriorly deep, posteriorly shallowing. Propodeum polished and with a less distinct medio-longitudinal sulcus. Hind femur 3.5 times as long as broad medially (Fig. 50). Inner spur of hind tibia just shorter than half basitarsus. Hind basitarsus as long as tarsomeres $2+$ half tarsomere 3 combined. Claw bifid, its basal lobe as in Fig. 51.

Fore wing just shorter than body. Pterostigma of right wing damaged (present its proximal third as in Fig. 52), left pterostigma missing, $r$ somewhat longer than width of pterostigma, 3-SR 1.9 times as long as $r$ and 1.6 times as long as 2-SR; SR1 bent, as long as $3-S R$ and reaching tip of wing; $3-S R$ and $2-M$ somewhat diverging distally (Fig. 52). First discal cell wide, 1-M 1.4 times as long as $m-c u, 1-S R-M$ bent and slightly longer than $1-M$ (Fig. 53). - Hind wing: $c u-a$ straight as in Fig. 54.

First tergite (Fig. 55) as long as broad behind, scutum with longitudinal striae and rugulosity. Second tergite less transverse, 1.5 times as broad behind as long medially, its median field bordered by crenulate sulcus, together with further tergites rugose. First tergite in lateral view as in Fig. 56. Ovipositor sheath almost as long as hind tibia.

Antenna black. Head and palpi yellow. Mesosoma testaceous with yellowish suffusion, three maculae of mesoscutum dark brown. Metasoma testaceous. Fore leg yellow. Middle leg brownish. Hind leg dark brown. Wings blackish brown fumous, pterostigma black, distal part of forewing with a wide pale yellow macula (or "fenestra").

Male and host unknown.

\section{Distribution:}

Cameroon.

\section{Taxonomic position:}

Mesobracon elegans is nearest to $M$. concolor SzÉPLIGETI (Kenya, Mozambique, Tanzania) and M. pulchripennis
Szépligeti (Republic of Congo, Malawi, Uganda, Democratic Republic of Congo = Zaire), the three species are very similar to each other and differ in the few features keyed:

1 (2) Wings blackish brown fumous, fore wing apically with a large whitish "fenestra"; pterostigma entirely blackish. Second submarginal cell fairly long, 3$S R 1.5$ times as long as $2-S R, S R 1$ as long as $3-S R$ (Fig. 52). Second tergite 1.5 times as broad behind as long laterally (Fig. 55). Metasoma testaceous. 우: $15 \mathrm{~mm}$. M. elegans SzÉPLIGETI, 1913

2 (1) Either proximal third of wings yellow (distal twothirds dark brown) or ground colour of wing yellow with transverse brown streaks; pterostigma yellow, apically brown, second submarginal cell either short or long, i.e. 3-SR 1.5 times or 1.8-2 times as long as 2-SR (Figs 57, 60).

3 (4) Distal two-thirds of wings dark brown fumous, fore wing apically with a small white "fenestra" (along vein $r-m)$. Second submarginal cell short and somewhat widening distally, 3-SR 1.5 times as long as 2-SR, SR1 bent and 1.3 times as long as 3-SR (Fig. 57). Second tergite 1.8 times as broad behind as long medially, tergites 1-2 densely rugose (Fig. 58). First tergite in lateral view somewhat pointed dorsally (Fig. 59). Metasoma brownish yellow. $+: 14 \mathrm{~mm}$.

M. concolor SzÉPLIGETI, 1906

4 (3) Ground colour of wings yellow, fore wing with three and hind wing with two transverse brown streaks. Second submarginal cell long and not widening distally, 3-SR twice as long as 2-SR, SR1 faintly S-form and as long as 3-SR (Fig. 60). Second tergite twice as broad behind as long medially, tergites imbricate (Fig. 61). First tergite in lateral view not pointed dorsally (Fig. 62). Metasoma brownish yellow to testaceous, apically blackish (1 ㅇ). ㅇ : 16-19 mm. M. pulchripennis SzÉPLIGETI, 1902

Remark - Redescriptions of five Mesobracon species were presented by PAPP (2009): three species described by SzÉPligeti: M. concolor SzÉPligeti, 1906, M. pulchripennis SzÉPligeti, 1902, M. similis SzÉPligeti, 1906 and two species by Brues: M. litura (BRUes, 1846), M. rugosus (BRUES, 1846).

\section{Plaxopsis pulchricaudis SzÉPLIGETI (Figs 63-72, 75)}

Plaxopsis pulchricaudis SzÉPLIGeTI, 1913: 383, female(s) type locality: "Kamerun", female lectotype (hereby designated, examined in 2005) in Senckenberg Deutsches Entomologisches Institut, Müncheberg; examined. 
Lasiophorus pulchricaudis (SzÉPLIGETI): FAHRINGER 1931: 340 (in key) and 356 (redescription). SHENEFelt 1978: 1693 (literature up to 1931).

\section{Generic affinity:}

According to VAN ACHTERBERG's "Key to the genera of Braconinae with facial protuberance" (VAN ACHTERBERG 1983: 177-178) SzÉPligeti's species P. pulchricaudis is representing the genus Plaxopsis SzÉPligeti, 1905. VAN Achterberg (l.c.) defines the genus with the following features: (1) face with prominent carina (Fig. 65, 66; Fig. 87 in VAN ACHTERBERg 1983: 197); (2) mesoscutum glabrous; (3) medio-basal field of second tergite wide (Figs 75, 77); (4) upper half of face protruding giving an odd joining place to the scape (Fig. 63); (5) tergites 4-5 behind flat (Figs 57 and 84 in VAN ACHTERBERG 1983: $195,197)$; (6) marginal cell of hind wing narrowed apically (Figs 72, 73, see arrows).

\section{Labels of the lectotype:}

(First label, printed) "Kamerun / Conradt"; (second label) "Plaxopsis + / pulchricaudis sp. n." (my handscript) / "det. Szépligeti" (printed) "1913" (my handscript), SzÉPLIGETI's original handscript label is reverse the second label; third label is the lectotype card. (Labels 2 and 3 were attached by me.) - Lectotype is in fairly good condition: (1) pinned by mesosoma (mesoscutum / prosternum); (2) both flagella distally deficient; (3) missing: right hind tibia + tarsus and left hind tarsus; (4) one ovipositor sheath glued on a separate card.

\section{Redescription of the lectotype:}

Body $13 \mathrm{~mm}$ long. Both antennae deficient distally. Scape sitting on a protuberance, in outer-lateral view 2.2 times as long as broad apically, ventrally a bit longer than dorsally, apically somewhat excised (Fig. 63). Right flagellum with 20 and left flagellum with 30 flagellomeres. First flagellomere 1.5 times as long as broad apically, further 9-10 flagellomeres shortening so that rest of flagellomeres cubic. - Head in dorsal view cubic (Fig. 64), almost 1.7 times as broad (between eyes) as long, eye somewhat protruding and shorter than temple, temple moderately rounded. Eye in lateral view nearly 1.4 times as high as wide, temple somewhat wider than eye and evenly wide beyond eye; face with a lamelliform protuberance (Fig. 65, see arrows). Face in frontal view medially with a short transverse and prominent carina, otherwise face rugulose, pair of tentorial pits fairly large and face close above pits somewhat impressed (Fig. 66). Horizontal diameter of oral opening somewhat longer than shortest distance between opening and eye. Third segment of maxillar palp less flattened (Fig. 67). Head polished.

Mesosoma in lateral view 1.6 times as long as high, together with propodeum polished. Notaulix weakly distinct. Hind femur 4.3 times as long as broad distally
(Fig. 68). Middle femur 4 times as long as broad medially. Middle basitarsus slightly longer than tarsomeres 2-3 combined. Claw fairly long and downcurved, with small basal lobe, pectinate (Fig. 69).

Forewing as long as body. Pterostigma (Fig. 70) 3.8 times as long as wide and issuing $r$ proximally from its middle, $r$ shorter than width of pterostigma. Second submarginal cell long and relatively narrow, 3-SR 2.7 times as long as 2-SR; SR1 almost straight, somewhat longer than 3-SR and approaching tip of wing. First discal cell wide, $1-M$ 1.3 times as long as $m-c u, 1-S R-M$ evenly curved and 1.4 times as long as $1-M$ (Fig. 71). - Hind wing: marginal cell distally narrowing, i.e. 1-2SR approaching tip of wing (Fig. 72 , see arrow); $c u-a$ straight.

First tergite (Fig. 75) 1.2 times longer than broad behind, evenly boadening posteriorly, pair of spiracles somewhat protruding, scutum longitudinally uneven. Second tergite less transverse, 1.2 times as broad behind as long laterally, antero-medially with a polished and wide field, otherwise tergite longitudinally striated (Fig. 75). Further tergites polished. Suture between tergites 2-3 bisinuate, deep and crenulated. Ovipositor sheath about one-third longer than body.

Antenna black. Body and legs tetaceous. Second tergite blackish, further tergites lightening brown. Hind tibia blackish brown. Wings blackish fumous, second discal cell basally (just below $2-S R-M$ ) with a whitish macula.

Male and host unknown.

\section{Distribution:}

Cameroon.

\section{Taxonomic position:}

Plaxopsis pulchricaudis is near to P. bifasciatus (SzÉPLIGETI) (Equatorial Guinea, Sierra Leone, Zaire) owing to their lamelliform protuberance on the face, the two species are separated by the features keyed:

1 (2) Eye in dorsal view slightly shorter than temple, temple moderately rounded (Fig. 64). First tergite 1.2 times as long as broad behind; second tergite less transverse, 1.2 times as broad behind as long laterally (Fig. 75). Pterostigma issuing $r$ clearly proximally from its middle, length of $r$ shorter than width of pterostigma; 3-SR 2.7 times as long as 2-SR, SR1 clearly longer than $3-S R$ and reaching tip of wing (Fig. 70). Marginal cell of hind wing approaching tip of wing (Fig. 72). Third segment of maxillar palp less flattened (Fig. 67). Scape twice as long as broad and less broadening apically (Fig. 63). Pterostigma entirely blackish. ㅇ : $13 \mathrm{~mm}$

P. pulchricaudis SzÉPligeti, 1913 
2 (1) Eye in dorsal view 1.7 times as long as temple, temple rounded (Fig. 76). First tergite 1.3 times as long as broad behind; second tergite transverse, 2-2.3 times as broad behind as long laterally (Fig. 77). Pterostigma issuing $r$ just proximally fom its middle, length of $r$ equal to width of pterostigma; $3-S R$ as long as 2-SR, SR1 somewhat longer than 3-SR and reaching tip of wing (Fig. 78). Marginal cell of hind wing reaching tip of wing (Fig. 73, see arrow). Third segment of maxillar palp more flattened (Fig. 74). Scape 1.5 times as long as broad and more broadening apically (Fig. 79). Pterostigma yellow, apically blackish brown. + : 10-15 mm

P. bifasciatus (SzÉPligeti, 1905)

\section{Serraulax conradti (SzÉPLIGETI)}

Iphiaulax conradti SzÉPligeti, 1913: 384, female(s) type locality: "Kamerun", female lectotype (designated as "holotype" by Quicke et Косн 1990: 223) in Senckenberg Deutsches Entomologisches Institut, Müncheberg; examined.

Serraulax conradti (SzÉPLIGETI): QUICKE \& КосH l.c. (comb. n., lectotype designation); PAPP (2011).

The female specimen was labelled as holotype. A redescription was published, illustrated with six line-drawn figures, and together with a further nine species its unambiguous recognition made possible by an identification key (PAPP 2011: 49-51, 67-70).

\section{Acknowledgement}

Herewith I take the opportunity of expressing my cordial thanks to Dr. Yves Gerard (Institut royal des Sciences naturelles de Belgique, Bruxelles), Dr. Jens-Peter Kopelke (Senckenberg Museum, Frankfurt a. M.) and Dr. Andreas Taeger (Senckenberg Deutsches Entomologisches Institut, Müncheberg) for supporting my taxonomic work with long-term loan period of type and other material.

\section{References}

AChterberg, C. van 1983: Six new genera of Braconinae from the Afrotropical region (Hymenoptera, Braconidae). - Tijdschrift voor Entomologie 126(9): 175-202.

AchterberG, C. van 1993: Illustrated key to the subfamilies of the Braconidae (Hymenoptera: Ichneumonoidea). - Zoologische Verhandelingen Leiden 283: 1-189.
Bradley, J. C. 1916: Taxonomic notes on Agathidinae (Hymenoptera, Braconidae). - Psyche (Cambridge) 23: 139-140.

Brues, C. T. 1924: Some South African parasitic Hymenoptera of the families Evaniidae, Braconidae, Alysiidae, and Plumeriidae in the South African Museum with a catalogue of the known species. -Annals of the South African Museum 19: 1-150.

BruEs, C. T. 1926: Studies on Ethiopian Braconidae, with a catalogue of the African species. - Proceedings of the American Academy of Arts and Sciences 61: 205-436.

EADY, R. D. 1968: Some illustrations of microsculpture in the Hymenoptera. - Proceedings of the Royal Entomological Society in London (A) 43: 66-72.

FAHRINGER, J. 1928-1935: Opuscula braconologica. Aethiopische Region. - Verlag F. Wagner in Wien, I: 1-635 + I-XIII + Tafel 1.

Harris, R. A. 1979: A glossary of surface sculpturing. Occasional Papers in Entomology 28: 1-31.

Muesebeck, C. F. W. 1927: A revision of the parasitic wasps of the subfamily Braconinae occuring in America north of Mexico. - Proceedings of the United States National Museum 69 (16): 1-73.

Nixon, G. E. J. 1941: New African and Oriental species of Microdus, NeEs, from known hosts (Hymenoptera, Braconidae). - Bulletin of Entomological Research 32: 111-118.

PAPP, J. 2009: A study of SzÉPLIGETi's types of Mesobracon species deposited in the Hungarian Natural History Museum (Hymenoptera, Braconidae: Braconinae). - Annales historico-naturales Musei nationalis hungarici 101: 81-99.

PAPP, J. 2011: Revision of the Serraulax Quicke species described by Szépligeti in the years 1905-1914 with description of a new species (Hymenoptera: Braconidae: Braconinae). - Acta Zoologica Academiae Scientiarum Hungaricae 57 (1): 43-73.

Quicke, D. L. J.; BrandT, A. P. \& FAlco, J. V. 2000: Revision of the Afrotropical species of Curriea AsHmeAD (Hymenoptera: Braconidae: Braconinae): a genus with diverse ovipositor morphology. - African Entomology 8 (1): 109-139.

SHARkeY, M. J. 1997: Subfamily Agathidinae. - In: Manual of the New World Genera of the Family Braconidae (Hymenoptera) No. 1: 69-83.

Shenefelt, R. D. 1970: Family Braconidae 3, Subfamily Agathidinae Förster. - Hymenopterorum Catalogus (nova editio), Pars 6: 307-428.

Shenefelt, R. D. 1978: Family Braconidae 10, Subfamily Braconinae, Gnathobraconinae, Mesostoinae, Pseudodicrogeniinae, Telengainae, Ypsistocerinae, plus Braconidae in general, major groups, unplaced genera and species. - Hymenopterorum Catalogus (nova editio), Pars 15: 1425-1872. 

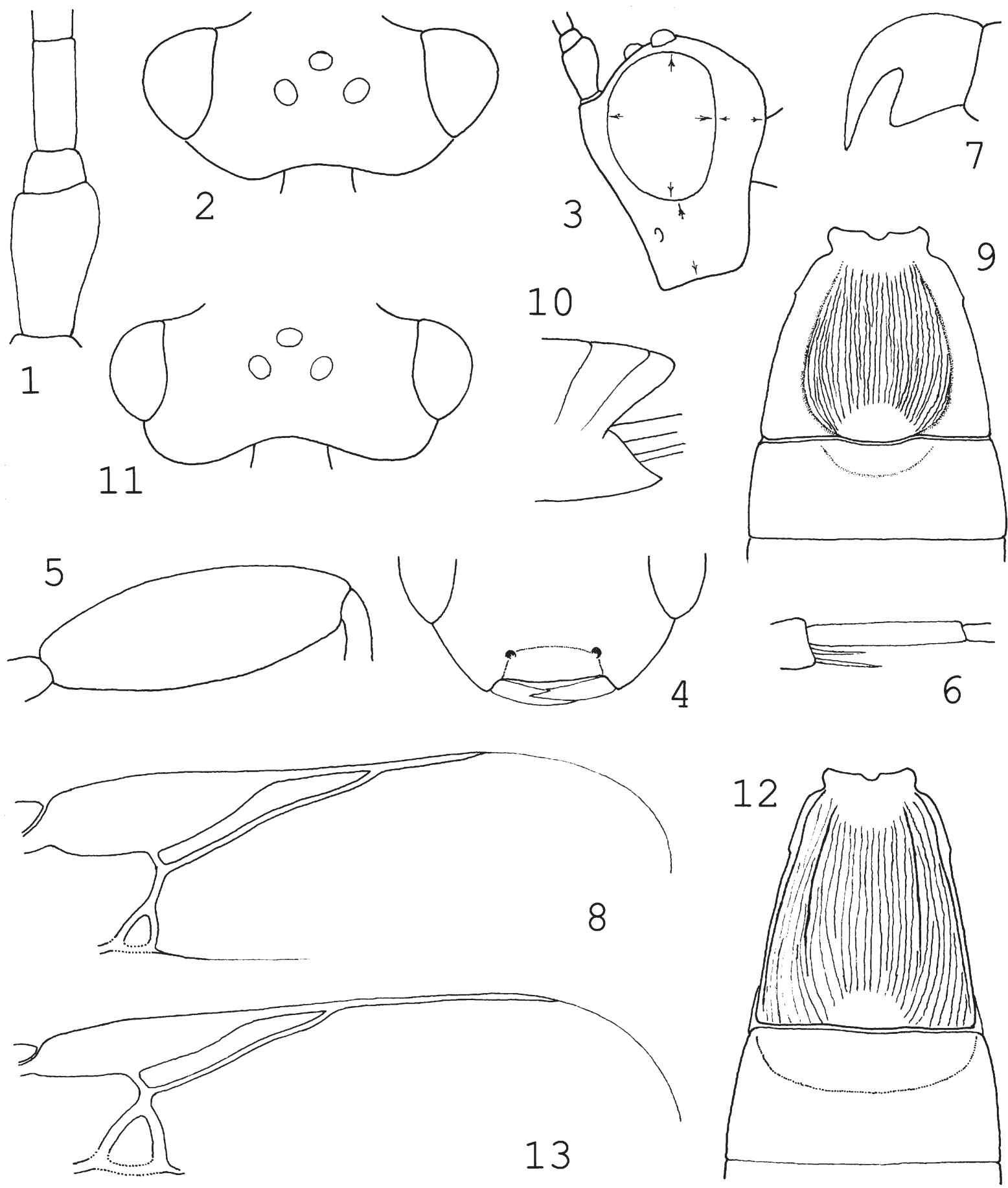

Figs 1-13: Figs 1-10: Bassus szepligetii nom. n. et comb. n. (female lectotype) - 1 scape, pedicel and first flagellomere in outer lateral view. -2 head in dorsal view. -3 head in lateral view. -4 head in frontal view. -5 hind femur. -6 pair of spurs and basitarsus of hind leg. -7 claw. -8 distal part of right forewing. -9 tergites 1-2. - 10 hind end of female metasoma. - Figs 11-13: Bassus conspicuus (WeSmael). - 11 head in dorsal view. - 12 tergites 1-2. - 13 distal part of right forewing. 

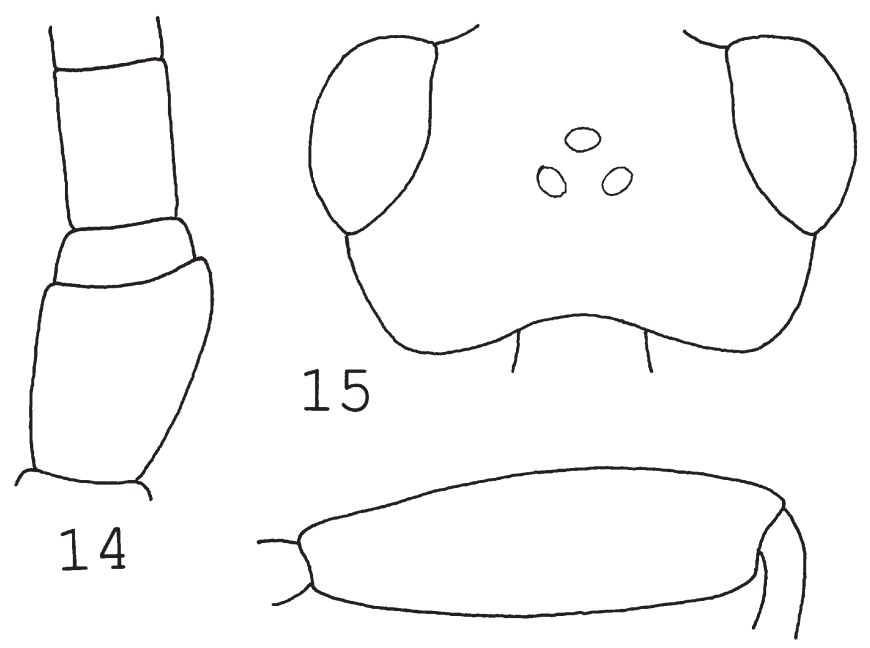

17
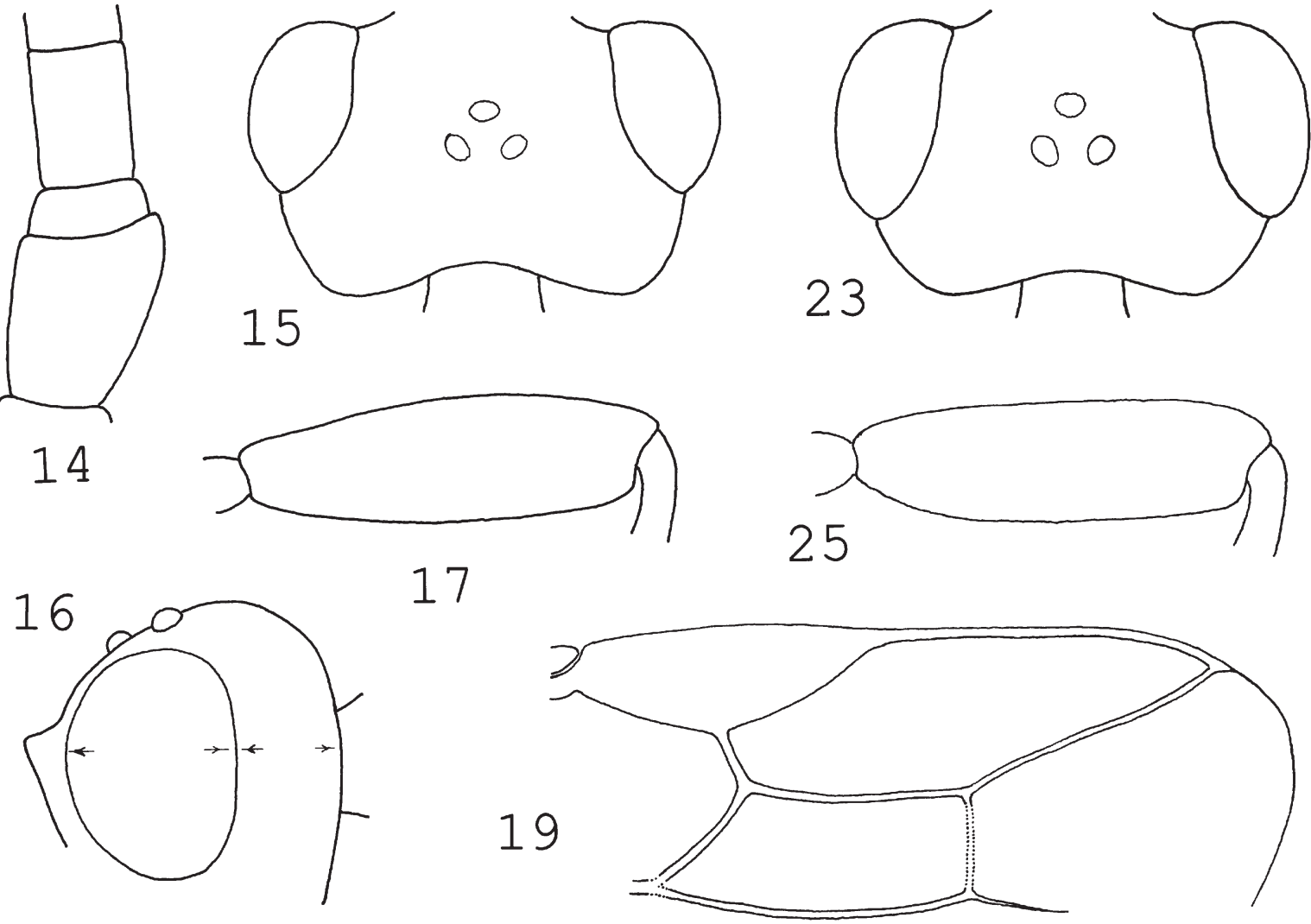

24
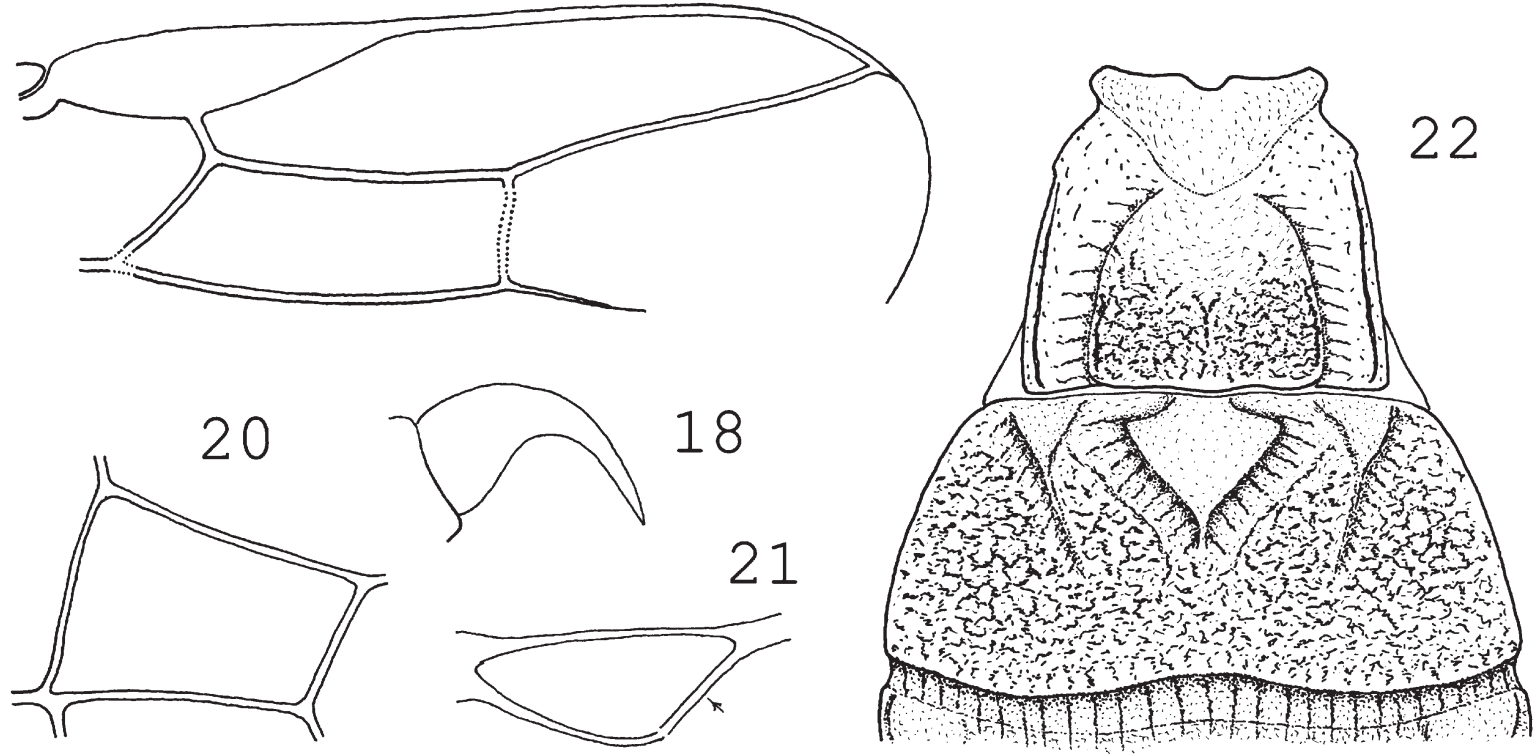

Figs 14-25: Figs 14-22: Campyloneurus similis SzÉPLIGETI, 1913 (female lectotype). - 14 scape, pedicel and first flagellomere in outer-lateral view. - 15 head in dorsal view. - 16 head in lateral view. - 17 hind femur. - 18 claw. - 19 distal part of right forewing. - 20 first discal cell of forewing. - 21 cu- $a$ of hindwing. - 22 tergites 1-2. - Figs 23-25: Campyloneurus basalis SzÉPLIGETI, 1906 (female holotype). -23 head in dorsal view. -24 distal part of right forewing. -25 hind femur. 

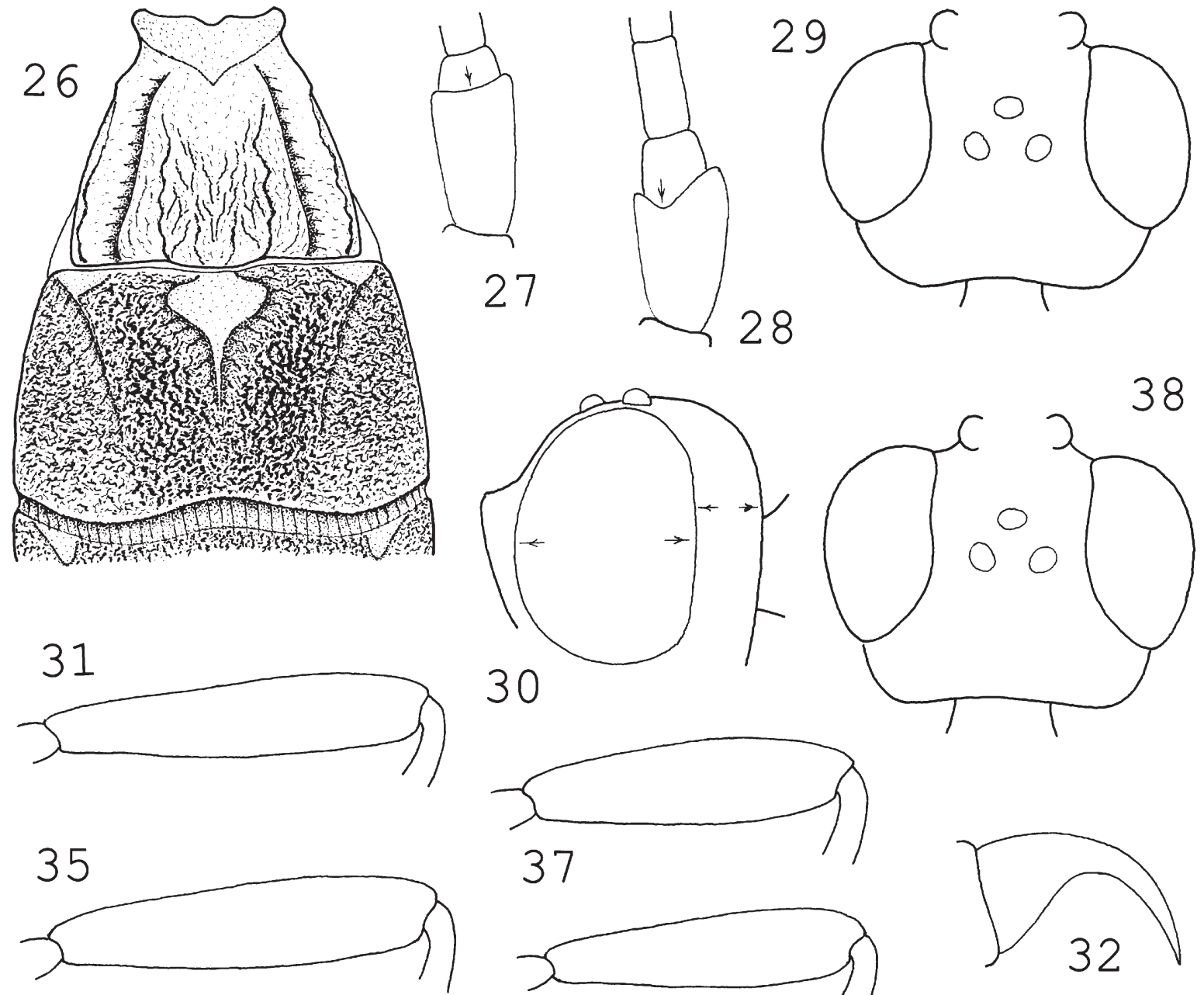

37
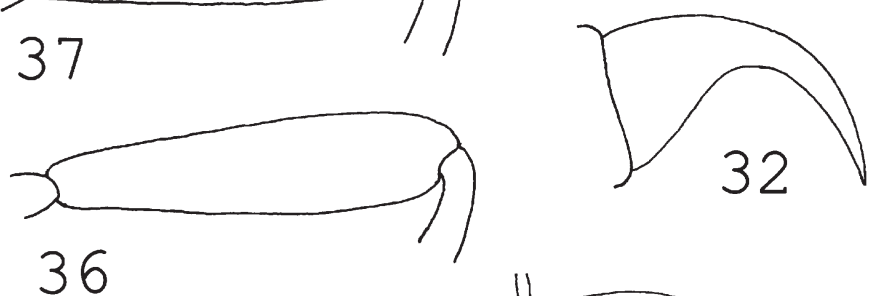

33
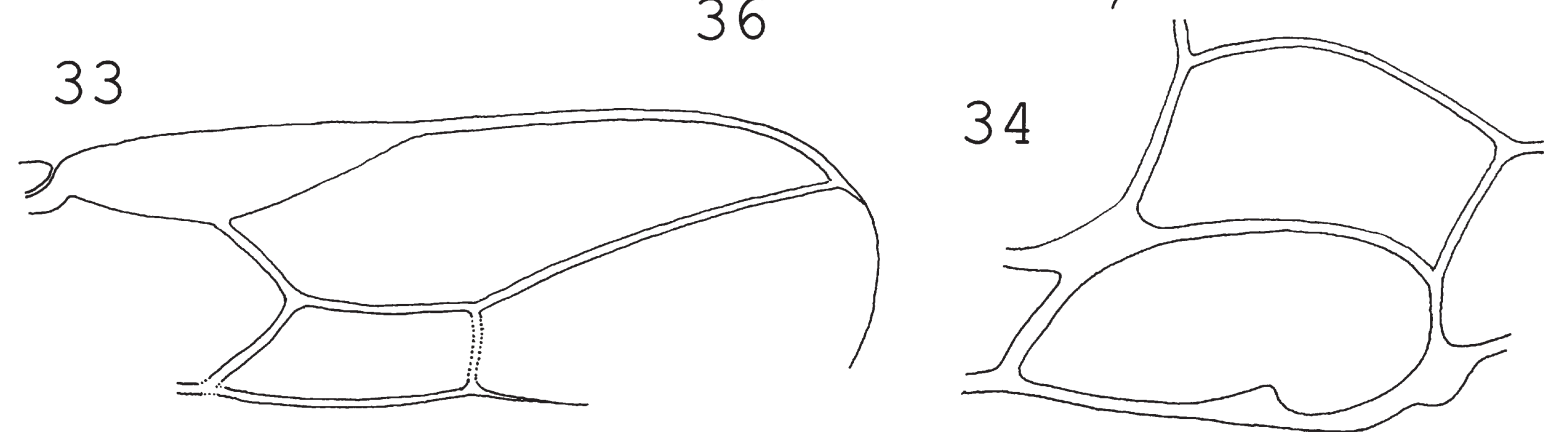

Figs 26-38: Fig. 26: Campyloneurus basalis SzÉPligeti, 1906 (female holotype). - 26 tergites 1-2. - Fig. 27: Aphrastobracon sp. 27 scape and pedicel in outer-lateral view. - Figs 28-35: Curriea nigriventris SzéPLIGETI, 1913 (28-34 male holotype of C. nigriventris. 35 female holotype of C. testaceipes SzéPLIGETI, 1914). - 28 scape, pedicel and first flagellomere in outer-lateral view. - 29 head in dorsal view. -30 head in lateral view. -31 hind femur. -32 claw. -33 distal part of right forewing. -34 first discal and first subdiscal cells of forewing. - 35 hind femur. - Figs 36-38: Curriea antefurcalis SzÉpligeti, 1915. - 36 hind femur of male. - 37 hind femur of female. -38 head in dorsal view. 

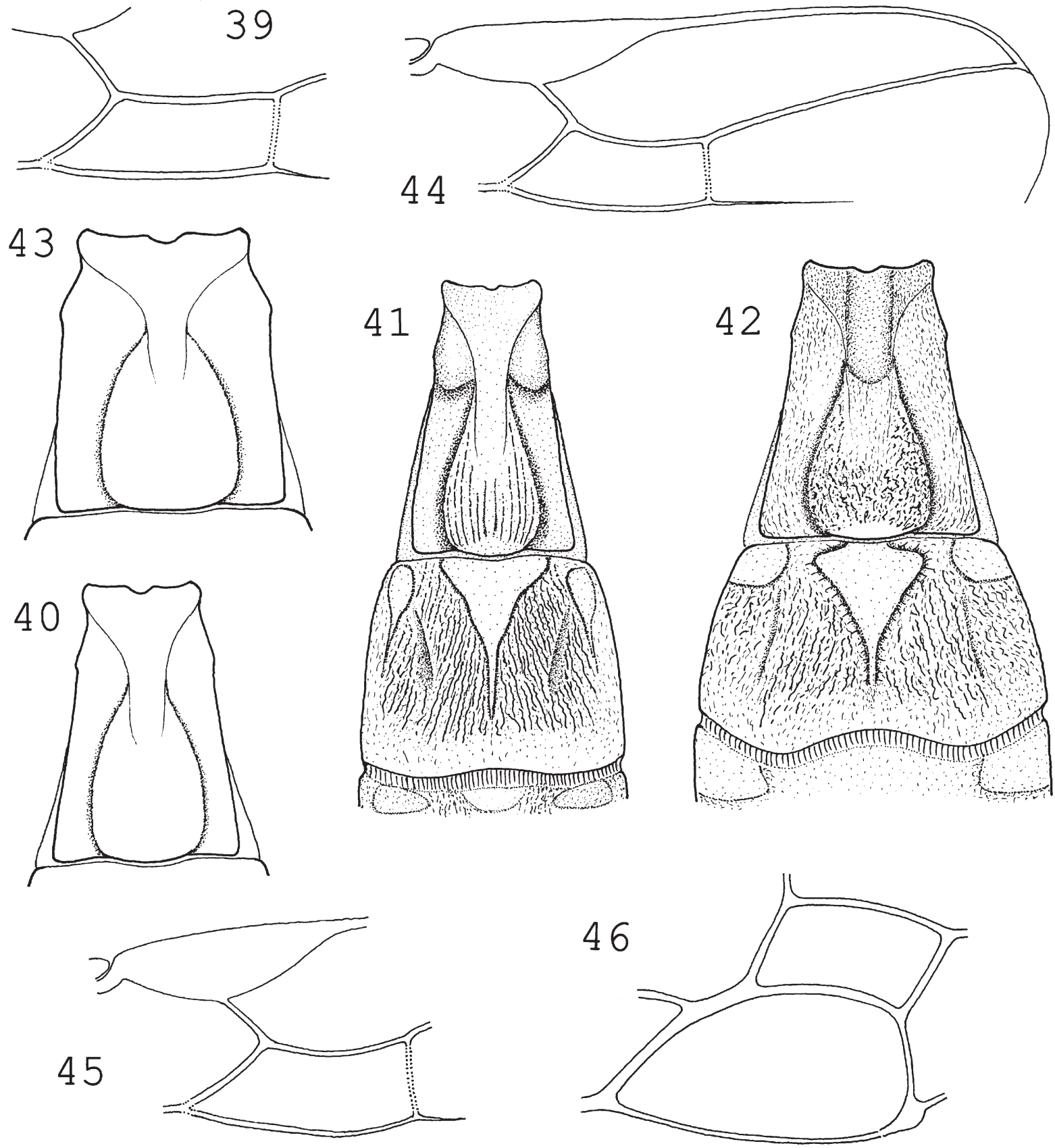

Figs 39-46: Figs 39-41: Curriea nigriventris SzéPLIGETI, 1913 (39-40 female holotype of C. testaceipes SzÉPligETI, 1914.41 male holotype of $C$. nigriventris). - 39 second submarginal cell and r. - 40 first tergite. - 41 tergites 1-2. - Figs 42-46. Curriea antefurcalis SzÉPligeti, 1915 (42-43 male. 44-45 female. 46 female and male) - 42 tergites 1-2. - 43 first tergite - 44 distal part of right forewing. - 45 pterostigma, $r$ and second submarginal cell of forewing. - 46 first discal and first subdiscal cells of forewing. 

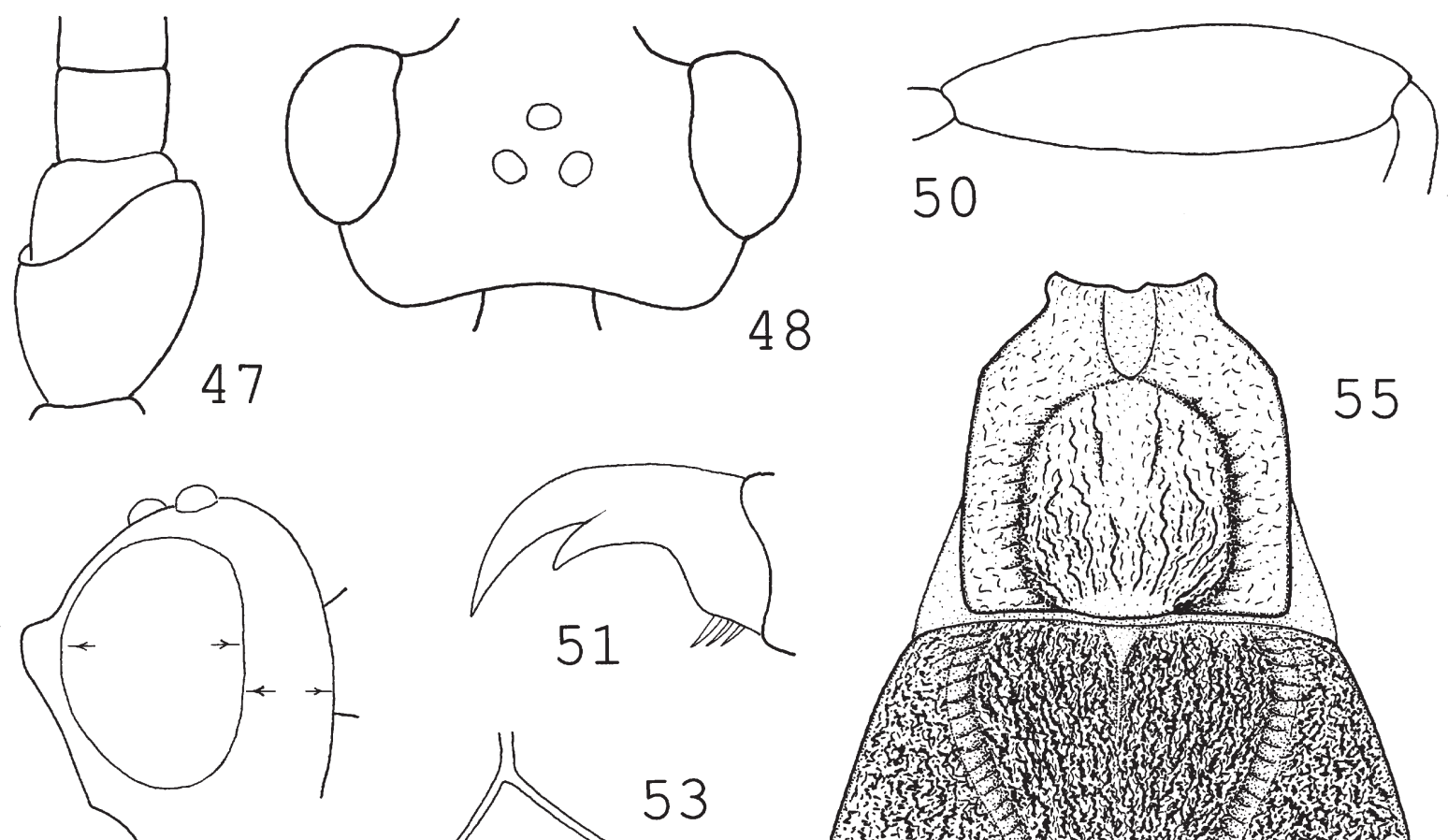

49
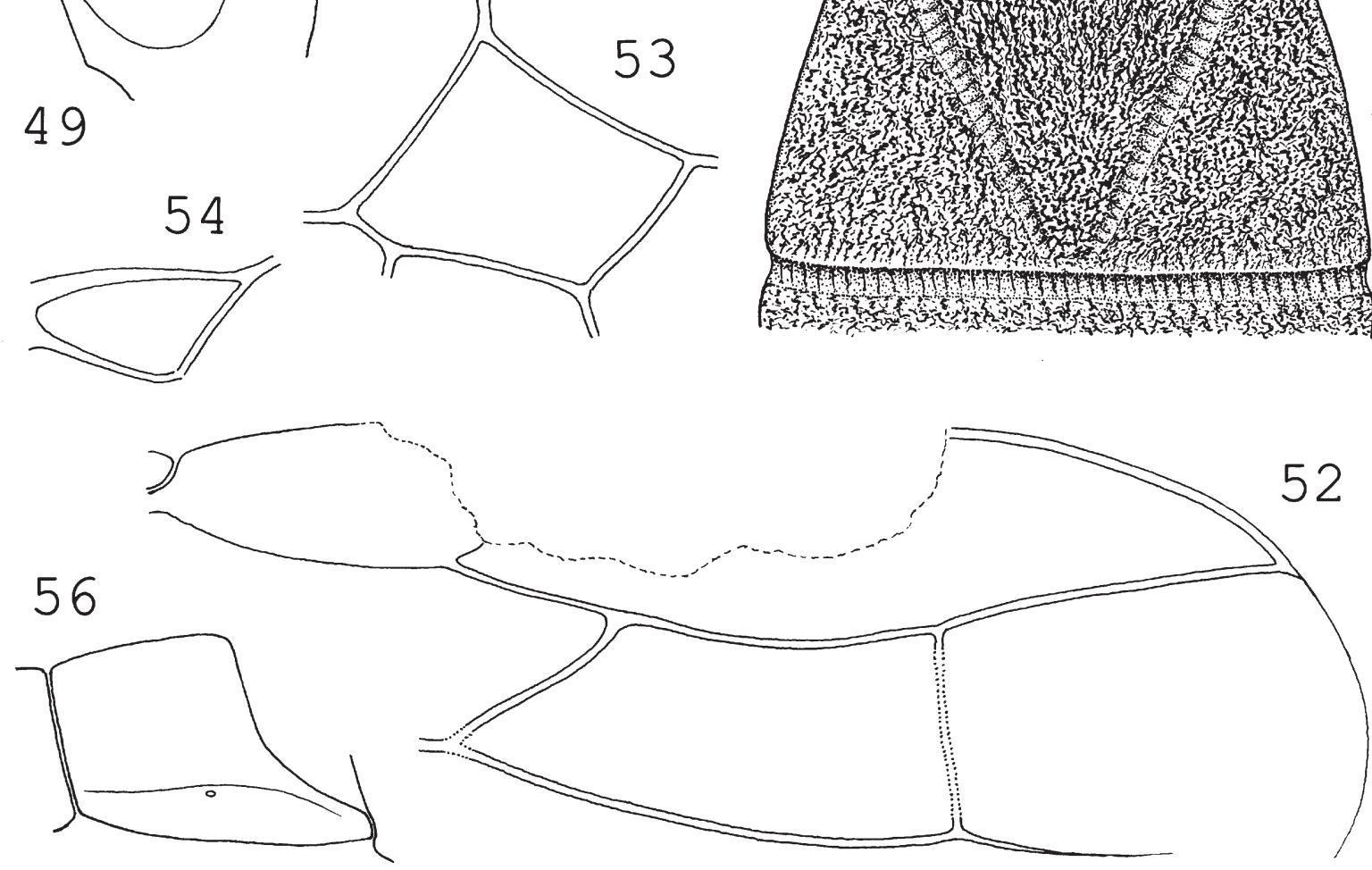

Figs 47-56: Mesobracon elegans SzÉPLIGETI, 1913 (female lectotype). - 47 scape, pedicel and first flagellomere in outer-lateral view. - 48 head in dorsal view. - 49 head in lateral view. - 50 hind femur. - 51 claw. - 52 distal part of right forewing (pterostigma deficient). -53 first discal cell of forewing. $-54 \mathrm{cu}-a$ of hindwing. -55 tergites 1-2. - 56 first tergite in lateral view. 

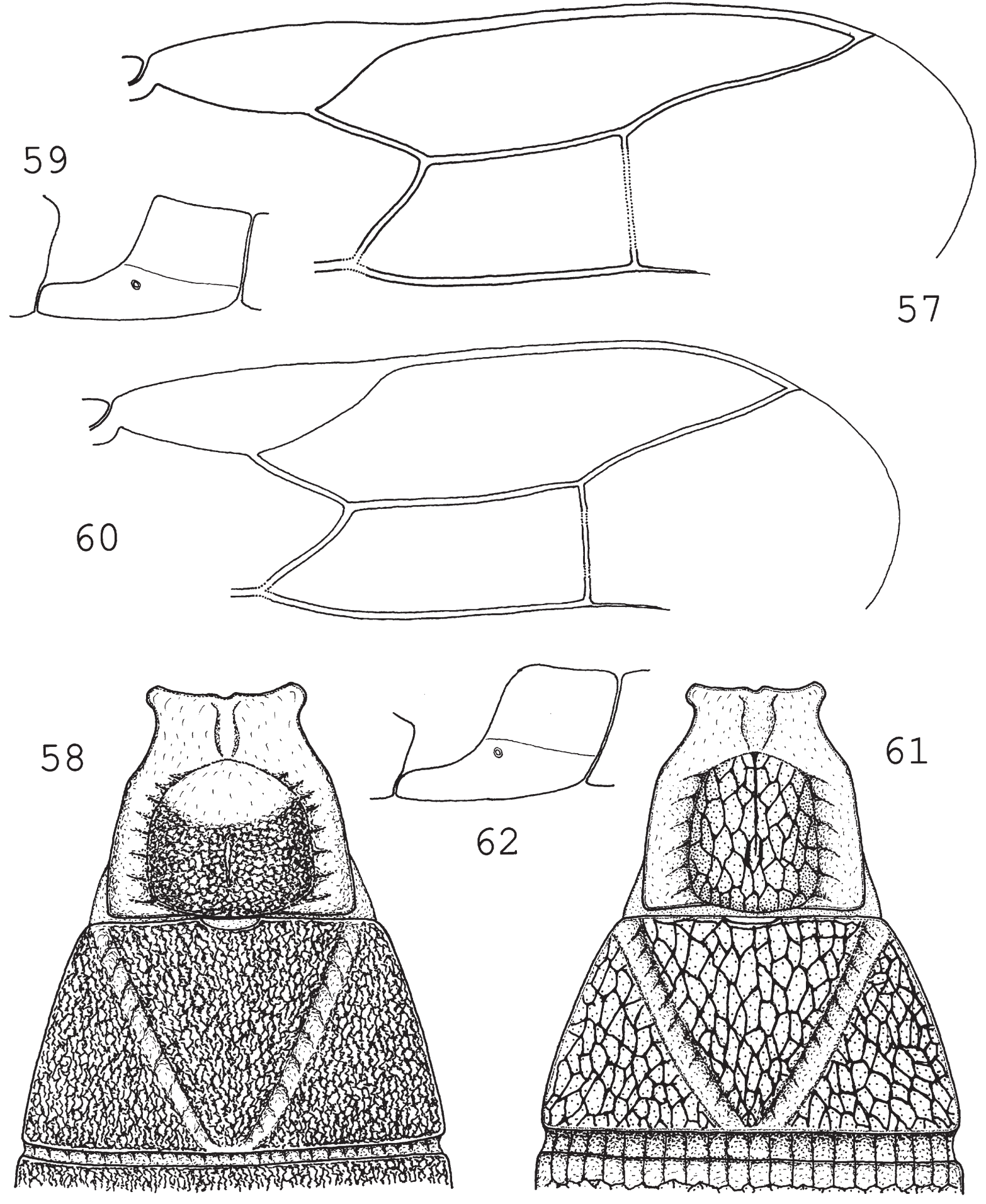

Figs 57-62: Figs 57-59: Mesobracon concolor SzÉPligeti, 1906 (female). - 57 distal part of right forewing. - 58 tergites 1-2. 59 first tergite in lateral view. - Figs 60-62: Mesobracon pulchripennis SzÉPLigeTI, 1902 (female). - 60 distal part of right forewing. -61 tergites 1-2. -62 first tergite in lateral view. 

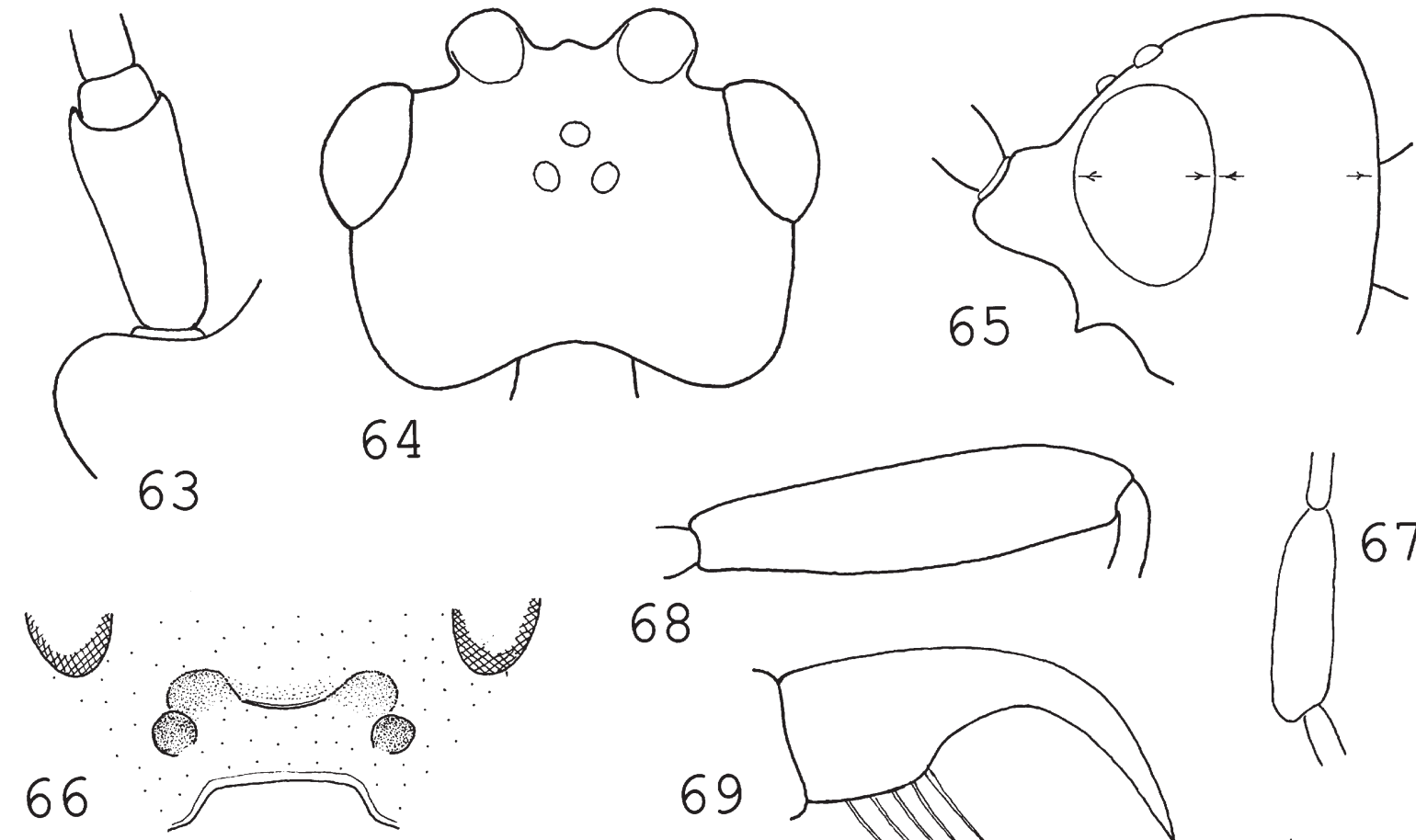

68

69
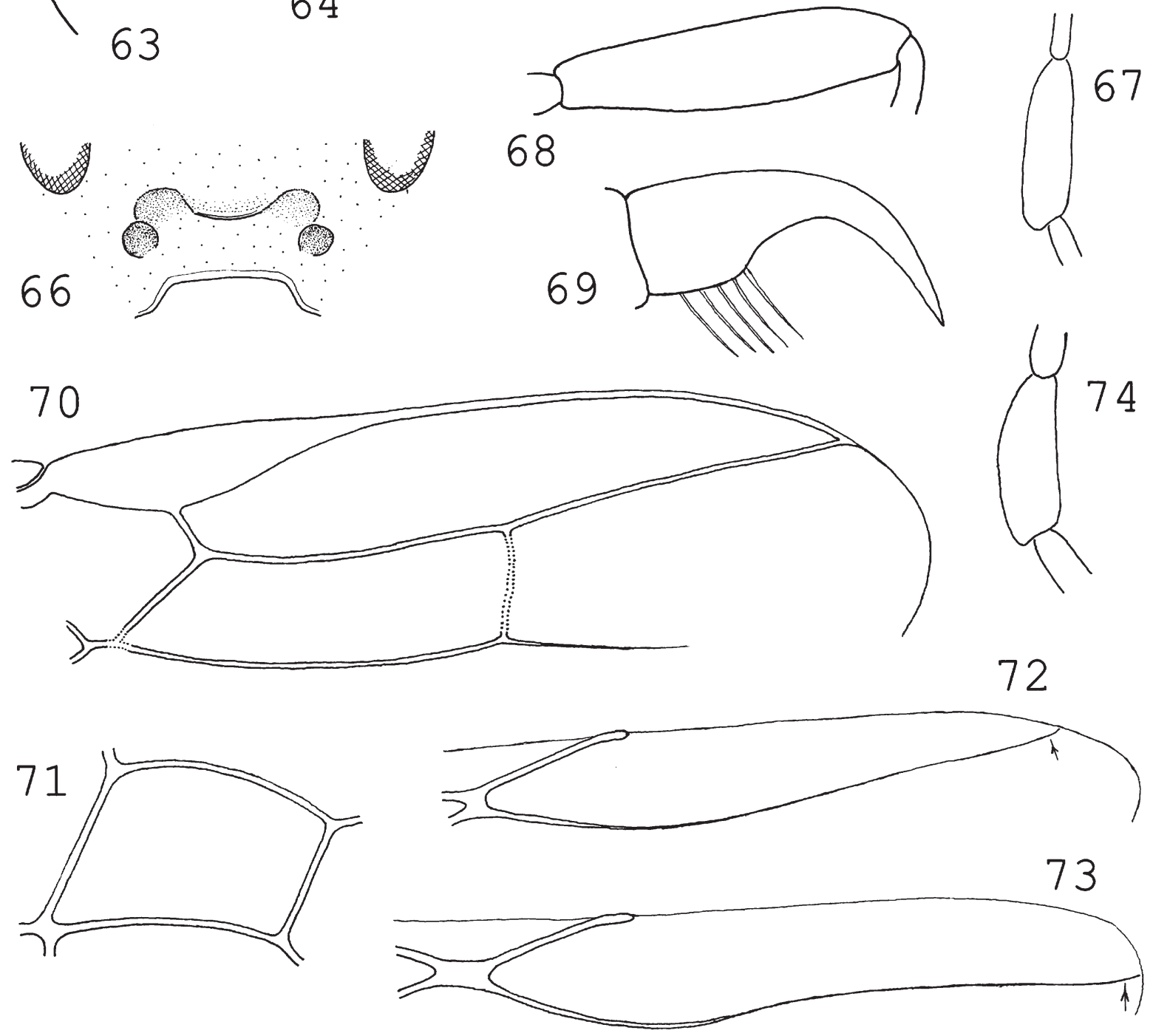

Figs 63-74: Figs 63-72: Plaxopsis pulchricaudis SzÉPLIGETI, 1913 (female lectotype). - 63 facial protuberance, scape and pedicel in outer-lateral view. -64 head in dorsal view. -65 head in frontal view. -66 face in lateral view. -67 third segment of maxillar palp. - 68 hind femur. - 69 claw. - 70 distal part of right fore wing. -71 first discal cell. - 72 marginal cell of hindwing. - Figs 73-74: Plaxopsis bifasciatus (SzÉPligeti, 1905) (female paralectotye). - 73 marginal cell of hindwing. - 74 third segment of maxillar palp. 

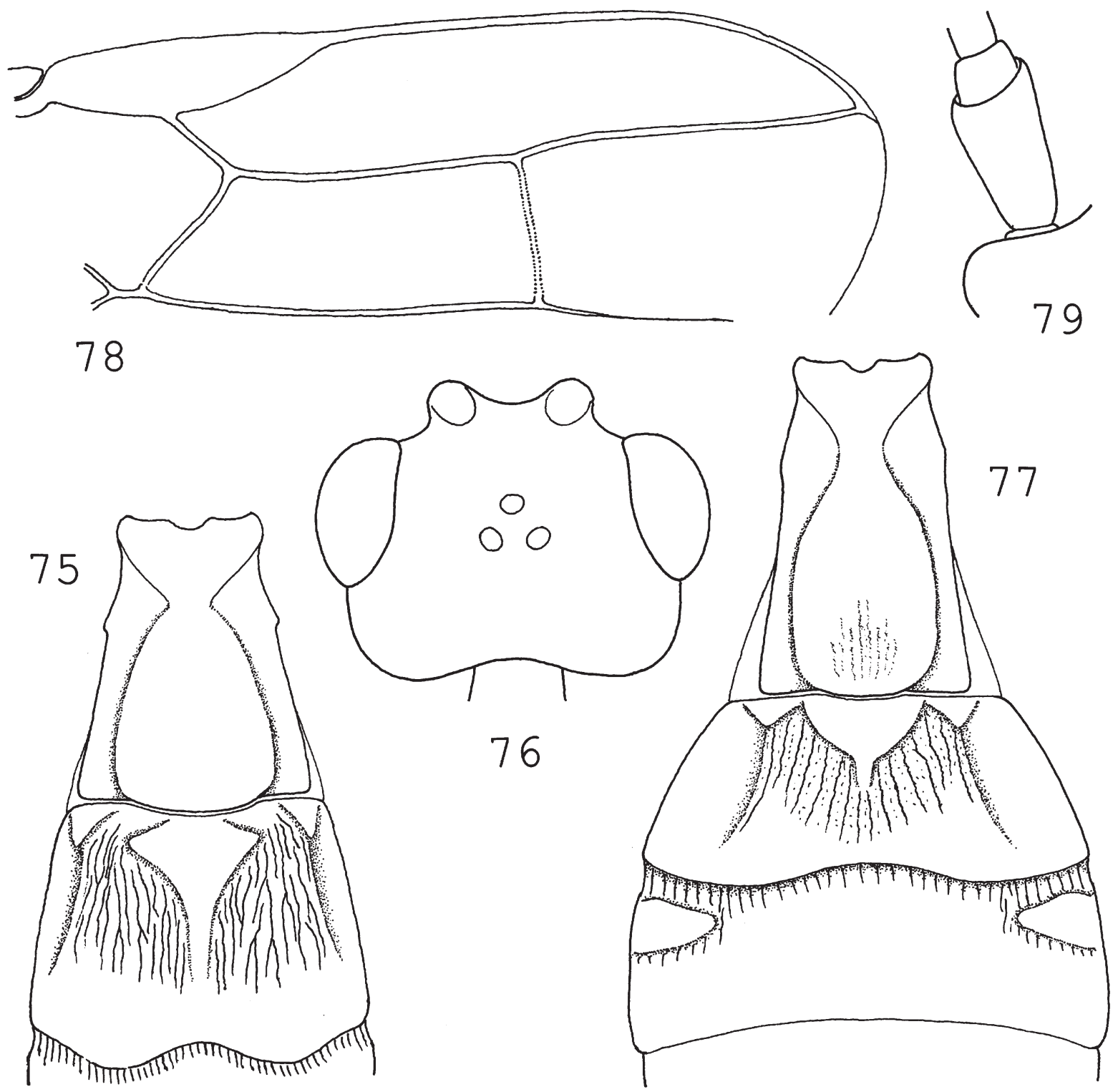

Figs 75-79: Fig. 75: Plaxopsis pulchricaudis SzÉPligeti, 1913 (female lectotype). - 75 tergites 1-2. - Figs 76-79: Plaxopsis bifasciatus (SzÉPLIGETI, 1905) (female paralectotype). - 76 head in dorsal view. - 77 tergites 1-3. - 78 distal part of right forewing. - 79 scape and pedicel in outer-lateral view.

SzÉPligeti, V. 1905a: Exotische Braconiden aus den aethiopischen, orientalischen und australischen Regionen. - Annales Musei Nationalis Hungarici 3: 25-55.

SzÉPligeti, V. 1905b: Beiträge zur Kenntnis der Insektenfauna von Kamerun. No 29. Braconidae. - Arkiv för Zoologi 2 (14): 1-11.

SzÉPligeti, V. 1906: Braconiden aus der Sammlung des Ungarischen National-Museums. I. Theil. - Annales Musei Nationalis Hungarici 4: 547-618.

Szépligeti, Gy. 1913: Afrikanische Braconiden des Deutschen Entomologischen Museums (Hymenoptera). - Entomologische Mitteilungen 2(12): 383-386.
SzÉPligeti, Gy. 1914a: Afrikanische Braconiden des Königl. Zoologischen Museums in Berlin. - Mitteilungen des Zoologischen Museums in Berlin 7: 154-230.

SzéPligeti, Gy. 1914b: Afrikanische Braconiden des Belgischen Naturhistorischen Museums. - Annales de la Société Entomologique Belge 58: 109-118.

SzÉPligeti, Gy. 1915: Braconidae. - Ergebnisse der zweiten Deutschen Zentral-Afrika Expedition 1910-1911 unter Führung A. Friedrichs, Herzog zu Mecklenburg 1 (Zool.): 139-154.

WATANABE, C. 1950: A preliminary revision of the genus Aphrastobracon AsHmeAd (Hymenoptera, Braconidae). - Journal of the Faculty of Agriculture, Hokkaido University, Sapporo, 48 (3): 291-304. 